\title{
ROCK BURST DEPENDENCY ON THE TYPE OF STEEL ARCH SUPPORT IN THE VELENJE MINE
}

\author{
HRIBINSKI UDARI V ODVISNOSTI OD VRSTE JEKLENIH \\ PODPORNIH LOKOV V PREMOGOVNIKU VELENJE
}

\author{
Goran Vižintin ${ }^{1}$, Janez Mayer ${ }^{2}$, Bojan Lajlar ${ }^{2}$, Željko Vukelić ${ }^{1}$ \\ ${ }^{1}$ University of Ljubljana, Faculty of Natural Sciences and Engineering, Aškerčeva Street 12, SI-1000 Ljubljana, Slovenia \\ ${ }^{2}$ Velenje Colliery, Partizanska 78, 3320 Velenje, Slovenia \\ goran.vizintin@guest.arnes.si
}

Prejem rokopisa - received: 2016-05-11; sprejem za objavo - accepted for publication: 2016-07-01

doi: $10.17222 / \mathrm{mit} .2016 .084$

\begin{abstract}
The Velenje Colliery is operating in the largest coal deposit in Slovenia and at the same time in one of the thickest known coal seams in the world. The lignite seam is at one point up to $165 \mathrm{~m}$ thick. Until now more than 220 million tons of lignite coal were extracted from this seam. The colliery is situated in the so-called Velenje depression, which is a component part of the Southern Karawanke geotectonic unit. Considering the coal mining we can claim that rock bursts are a kind of constant that accompany the mining activities and represent occasional difficulties during production and at the same time disturb the local inhabitants Based on complaints and at the same time because of the need for a thorough understanding of the causes of ground shaking, the Velenje Colliery decided for a systematic monitoring and evaluation of the seismic events. Based on these measurements the seismic events were precisely located and correlated to the technological process itself. Seismic events analysis indicates that these events are instantaneous stress relaxations piled up for a longer time because of the lignite extraction. This last statement can be confirmed by an analysis of the longitudinal seismic waving first arrivals $(\mathrm{P})$ to seismological stations of the state monitoring network of Slovenia, Austria and Italy, even though such events are rare because of their weakness. The same analysis showed that the magnitudes rarely reach over 1.5 of local magnitude after Richter. Simultaneously with the seismic events analysis we analyzed the way of support relaxation. Tests on the existing support type K24 showed that this support is capable of withstanding large stresses without deformation. From these tests we found that the stress relaxation at currently used support type K24 can occur over relatively large deformations. The relatively simple stress-relaxation analysis at existing support shows it surprisingly well match to the energy relaxed at rock bursts in Velenje Colliery. Based on research done between 2003 in 2012 it is possible to conclude that the existing support type must be replaced with one that can relax the stress more frequently and with less deformation, consequently reducing rock bursts and increasing safety at work.

Keywords: rock burst, steel arch, induced seismicity
\end{abstract}

Premogovnik Velenje deluje na največjem nahajališču premoga v Sloveniji, ki je hkrati eno takih, ki ima najbolj debele plasti premoga na svetu. Plast lignita je na enem mestu debela tudi do $165 \mathrm{~m}$. Do sedaj je bilo izkoriščenih 220 milijonov ton lignita iz te plasti. Premogovnik se nahaja v velenjski depresiji, ki je sestavni del geotektonskega dela Južnih Karavank. Pri rudarjenju premoga so hribinski udari konstanta, ki spremlja rudarske aktivnosti in občasno predstavlja težave pri proizvodnji ter istočasno moti lokalno prebivalstvo. Zaradi pritožb in hkrati zaradi potrebe po razumevanju vzrokov tresenja tal, so se v Rudniku Velenje odločili za sistematično registriranje in oceno seizmičnh pojavov. Na osnovi teh meritev so bili seizmični dogodki natančno locirani in povezani s samim tehnološkim procesom. Analiza seizmičnih dogodkov kaže, da gre za trenutne sprostitve napetosti, ki so se nakopičile v daljšem času zaradi ekstrakcije lignita. To trditev je mogoče potrditi z analizo longitudinalnih seizmičnih valovanj (P), ki pridejo prva do seizmoloških postaj državne kontrolne mreže v Sloveniji, Avstriji in Italiji, čeprav so taki dogodki redki zaradi šibkosti valov. Analiza je pokazala, da lokalna magnituda redko preseže 1,5 po Richterju. Istočasno z analizo seizmičnih pojavov smo analizirali način relaksacije podporja. Preizkusi na obstoječem podporju vrste K24 so pokazali, da to podporje lahko prenese večje napetosti brez deformacije. Iz teh preizkusov sledi, da se pri trenutni uporabljeni podpori vrste K24 lahko pojavijo sprostitve napetosti preko relativno velikih deformacij. Relativno preprosta analiza sproščanja napetosti je pokazala dobro ujemanje $\mathrm{z}$ energijo sproščeno pri hribinskem udaru v premogovniku Velenje. Na osnovi raziskav, opravljenih med 2003 in 2012, je mogoče zaključiti, da je obstoječo vrsto podporja potrebno zamenjati s tako, ki lahko bolj pogosto sprošča napetosti in $\mathrm{z}$ manj deformacije, kar omogoča manj hribinskih udarov in poveča varnost pri delu.

Ključne besede: hribinski udari, jekleni lok, povzročena seizmičnost

\section{INTRODUCTION}

Velenje Colliery is situated in the northern part of Slovenia in the so-called Velenje depression, which is a component part of the Southern Karawanke geotectonic unit. Southern Karawanke form the northern part of the Velenje depression and the northern part of its basement reaching from the Smrekovec fault in the north to the Velenje fault in the south. On the northern margins of the depression the layers of Triassic dolomite are slightly folded, but from the depression margin the Triassic dolo- mite is steeply inclined towards the southeast. North of Topolšica we can find the outcrops of Upper Carboniferous and Lower Permian age. The black shale, the quartz sandstone and conglomerate and the grey limestone are typical. In the vicinity of the Velenje fault there is a minor parallel fault along which the zone of Paleozoic husks is present. This zone consists of quartz conglomerate, shale and limestone. ${ }^{1}$ The Velenje depression is a component part of a larger Velenje-Dobrna depression. The depression is placed between the Velenje fault in the north and the Šoštanj fault on the southern 


\section{MATERIALI IN TEHNOLOGIJE/MATERIALS AND TECHNOLOGY (1967-2017) - 50 LET/50 YEARS}

\section{G. VIŽINTIN et al.: ROCK BURST DEPENDENCY ON THE TYPE OF STEEL ARCH SUPPORT IN THE VELENJE MINE}

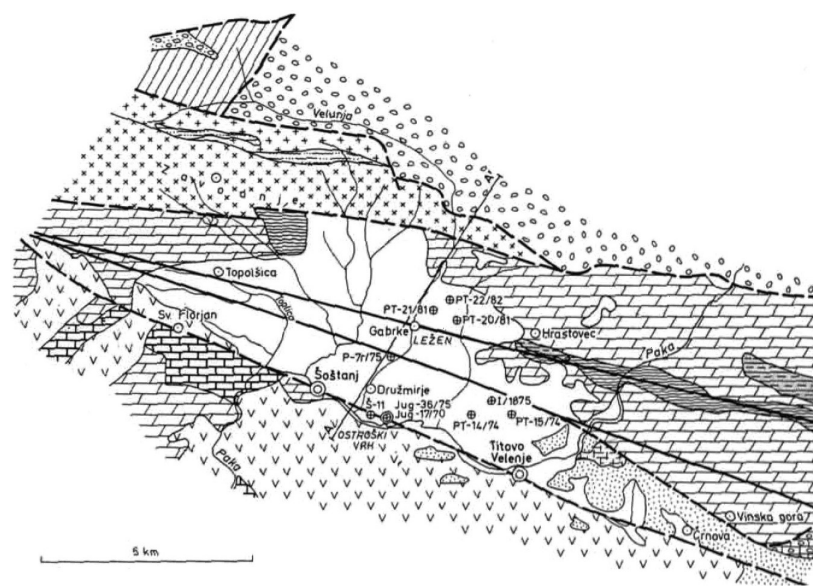

Figure 1: Geologic map of the Velenje depression and the surroundings 1

Slika 1: Geološka mapa velenjske depresije in okolice ${ }^{1}$

edge following the quite right shape of the depression or a basin. The origin of the depression dates into the Styrian orogenic phase (Lower Miocene). At that time of general uplift of the territory, the Badenian lithotamnic limestone was sedimented upon the Egerian and Eggenburgian basement made of andesitic tuff and marly clay. North of the Velenje fault the Karawanke were ashore yet. At the end of Badenian period the sea withdraws. In the terrestrial phase in the Athic orogenic phase (lower Pliocene) the majority of Miocene sediments were eroded. The depression started to sink in the Rodian tectonic phase (middle Pliocene) as the upper Pliocene strata are proved yet in the roof of the coal seam. $^{2}$ As shown by boreholes that were bored through the Pliocene coal-bearing strata, the depression continued to sink through the complete Upper Pliocene. ${ }^{1}$ The Gorenje-ŠSoštanj block is situated south of Šoštanj fault.
This block is built mostly of Oligocene andesitic tuffs and marly clay. Nearby these volcanic and clastic sediments there are some outcrops of Triassic dolomite and upper Permian black limestone found western and northwestern from Ššstanj ${ }^{1}$ (Figures 1 and 2).

The coal seam of Pliocene age is syncline shaped and as such adapted to the paleomorphological and geological characteristics of the observed area. Along the Šoštanj fault the coal seam is thicker, but gets thinner towards the northeast. The thickening is also attributed to major sinking in the area around the Šoštanj fault. The deposit, represented with this single coal seam is $8.3 \mathrm{~km}$ long and round $1.5 \mathrm{~km}$ wide. In some areas around the Šalek valley there can be found other coal appearances in the shape of high ash coal layers, black organic clays, brown organic silt and clay. The depression is filled up with the sediments of Pliocene and Pleistocene age. The component parts of the depression fill are alternating layers of clays, silts, sands, pebbles, claystones, siltstones, marls and conglomerates. In-between the Velenje coal seam is placed. ${ }^{3}$ The sedimentary fill of the depression represents the complete sedimentation cycle, reaching from the terrestrial phase over marshy phase to the lacustrine phase. The floor strata are of Pliocene age and up to $400 \mathrm{~m}$ thick. In the lower part the floor is made of particles from surrounding rocks but higher the clay, silt and sands are present. These materials represent the first, lacustrine fill of the depression, but further on the sinking continued much more slowly and in the marshy environment a lot of organic substance has been deposited. Above the floor strata there are organic clays and high ash coal that pass into more pure coal. The coal seam thickness reaches up to $165 \mathrm{~m}$ at one point, but is on average around $60 \mathrm{~m}$. After the marshy phase the sinking of the depression continued in the way that the

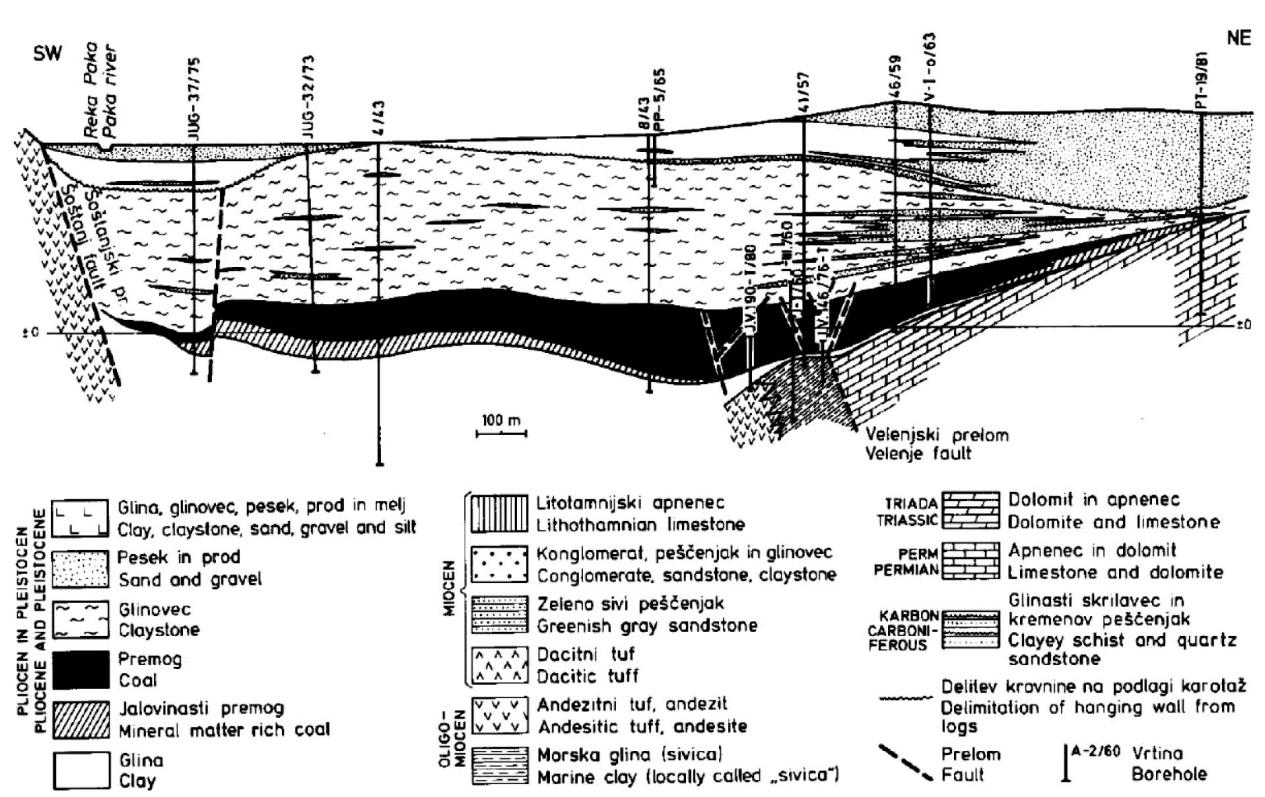

Figure 2: Cross-section through the Velenje depression oriented NE-SW, with underground outline of the coal seam ${ }^{3}$ Slika 2: Presek skozi velenjsko depresijo, orientirano SV-JZ s podzemnim prikazom ležišča premoga ${ }^{3}$ 


\section{MATERIALI IN TEHNOLOGIJE/MATERIALS AND TECHNOLOGY (1967-2017) - 50 LET/50 YEARS}

G. VIŽINTIN et al.: ROCK BURST DEPENDENCY ON THE TYPE OF STEEL ARCH SUPPORT IN THE VELENJE MINE

lake formed again and the roof sediments slowly filled the lake. Also above the coal there are Pliocene and Pleistocene sediments represented mainly by clays, sandy clays, mudstones and sands (Figure 2).

\section{THE MINING METHOD}

After 1970 the specially adapted longwall mining method has been developed in the Velenje Colliery. This method is tailored to great seam thickness and coal seam geometry, using a mechanized hydraulic shield roof support. Besides coal extraction the fill-in and hardening of the goaf behind the support is enabled. The coal is extracted in levels that follow each below other from the roof towards the floor. The longwall face is kind of divided into the upper and lower sectors. Longwall faces in the Velenje Colliery are $160 \mathrm{~m}$ to $200 \mathrm{~m}$ wide. The mine design imposes the extraction from edge of the seam towards the centre in slices that are from $400 \mathrm{~m}$ to $800 \mathrm{~m}$ long and from $3 \mathrm{~m}$ to $15 \mathrm{~m}$ high. The working process is completely mechanized using the hydraulic shield support and the shearer that cuts the coal. There is a chain conveyor installed to transport the coal from the

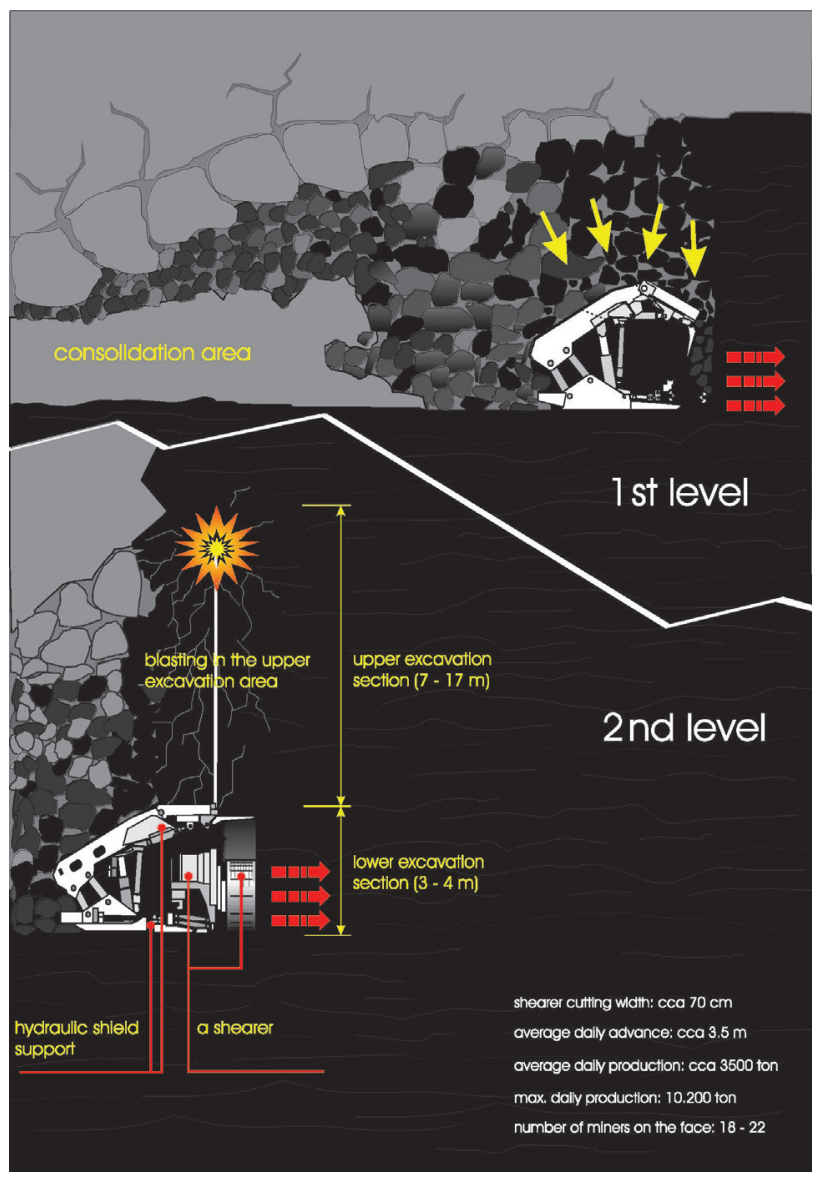

Figure 3: Cross-section of the hydraulic shield support with the principle of mining in the Velenje Colliery 4

Slika 3: Presek hidravlične varovalne podpore $\mathrm{z}$ načinom izkopavanja v rudniku Velenje ${ }^{4}$ lower and the upper sector of the face. Coal extraction follows the retreating method where the designed block is developed to its boundary first and then mined back. Development means to elaborate the supply roadway (travel road or main gate or head gate) and the haulage roadway (belt road or tail gate), make the connection between them with the face roadway and enable the ventilation. As the chocks are installed the face advances and the shearer and shield support move forward and the goaf increases. This goaf collapses under the weight of the overlying strata. The upper sector of the face is won by slow movements of the canopy as the stress crushes the coal. The working cycle is complete when all the coal from the upper sector comes down. The working height of the face can be limited by calculation involving the thickness of the isolating clay layer above the coal seam. This clay layer protects the face against inrushes of water bearing sands. ${ }^{4}$ Considering the Velenje mining method the most important parameters are fractures in the rock and a roof strata collapse. This has to do with excavation principles and advancing techniques of mining. Because of the use of natural forces in the mining process the upper sector is a basis of high productivity of the face (Figures 3 and 4). Subsidence of
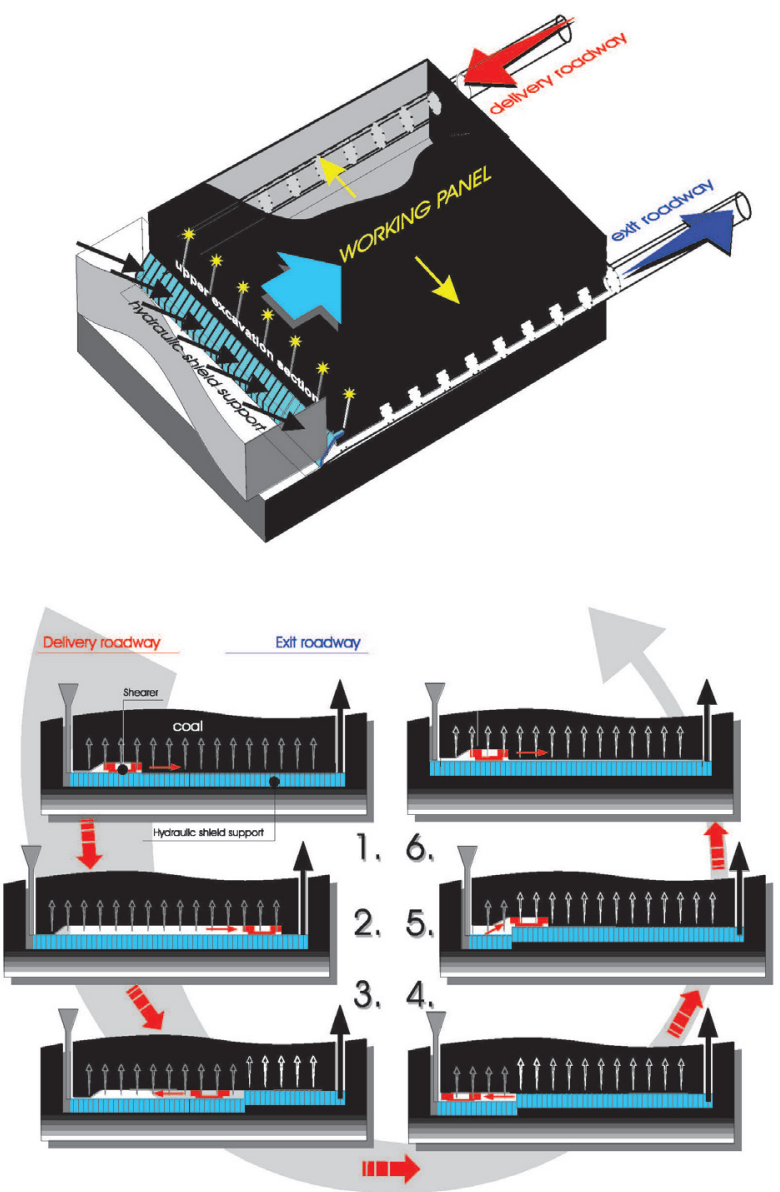

Figure 4: Layout of the longwall face with separate phases of coal extraction $^{4}$

Slika 4: Izgled širokega čela z ločenimi fazami izkopavanja premoga ${ }^{4}$ 


\section{MATERIALI IN TEHNOLOGIJE/MATERIALS AND TECHNOLOGY (1967-2017) - 50 LET/50 YEARS}

\section{G. VIŽINTIN et al.: ROCK BURST DEPENDENCY ON THE TYPE OF STEEL ARCH SUPPORT IN THE VELENJE MINE}

the surface above excavated longwall faces resulted in formation of three subsidence lakes.

\section{INDUCED SEISMICITY}

Each change of natural stress condition in the Earth's interior can result in a rock relaxation. The most common are the natural changes of the stress-state conditions, but starting with the extraction of raw materials the induced seismic events can be very frequent too. Seismicity in mines depends on mining depth and mining geometry, production percentage, geological anomalies (faults, dykes) and tectonic pressures. In an underground roadway the deformation and stress energy rise with depth and at the same time the possibility of a rock burst rises too, applied to all the roadway cross-section shapes. ${ }^{5}$ Rock burst by definition is a powerful collapse of the rock, occurring quite periodically in underground mining. Rapid excavation is followed by sudden rock collapse parallel to the face, inducing rock bursting. Most often the rock bursts are observed in hard and deformable rocks ${ }^{6}$, at processes of space enlargements caused by rapid excavation in mines and collieries. The development of better excavation methods of raw materials enabled the rise of production, but also caused rapid adjacent rock instability and seismic events occurrence. Due to seismic events increase, the systematic monitoring begun and resulted the finding of rock bursts mechanisms. J. C. Johnston and H. H. Einstein ${ }^{7}$ suggested six of them:

- Ore excavation at high vertical roof pressure;

- Roof collapse in underground roadway;

- Slipping along existing fault;

- Rock collapse in front of the advancing face;

- Fractured rock at the active face and on the opposite side of the face due to pressure growth;

- Bearing pillar collapse.

Based on further geological research and seismic record analyses, J. C. Johnston and H. H. Einstein ${ }^{7}$ defined two rock burst types shown in Table 1. Relation at Type I depends primarily on mining, longwall face rating and blasting schedule. Upper magnitude limit of the

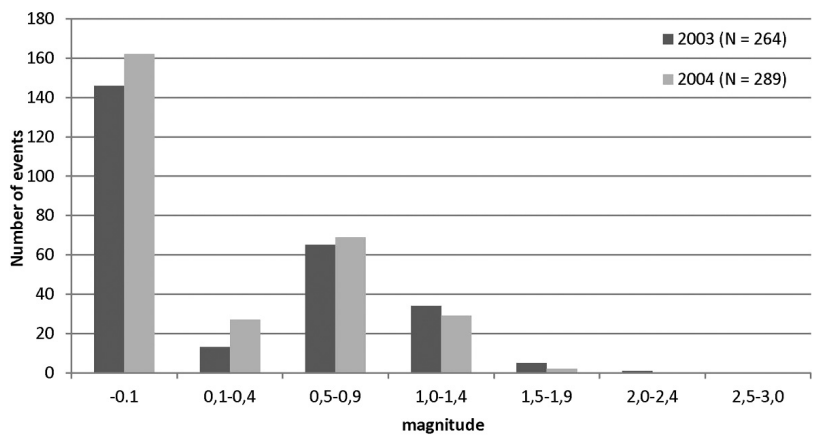

Graph 1: Number of events of specific magnitudes in the years 2003 and 2004

Graf 1: Število dogodkov s specifično magnitude v letih 2003 in 2004
Type I depends on the rock strength, but the epicenter location depends on the position of the mining site and its geometry. Rock burst intensity at Type II depends on thge interaction between induced stress in mine area, tectonic stress area and fault possibility. Excavation depth is another one of the important criteria. Shallow mining can induce seismicity, but it is depending on a large number of parameters, like face depth, face rate, face geometry, tectonic stress, mining stress, fault zone proximity regarding face position ${ }^{7}$ (Table $\mathbf{1}$ ).

Table 1: Rock burst types ${ }^{7}$

Tabela 1: Vrste drobljenja kamenine ${ }^{7}$

\begin{tabular}{|l|l|}
\hline \multicolumn{1}{|c|}{ TYPE I } & \multicolumn{1}{c|}{ TYPE II } \\
\hline $\begin{array}{l}\text { In general the relation is a } \\
\text { function of mining activity. }\end{array}$ & $\begin{array}{l}\text { There are not enough data to } \\
\text { define the relationship to } \\
\text { mining relations. }\end{array}$ \\
\hline $\begin{array}{l}\text { Location is round } 100 \mathrm{~m} \\
\text { inside of the face or inside } \\
\text { existing weakness zone or the } \\
\text { geological anomaly is close } \\
\text { to the mine. }\end{array}$ & $\begin{array}{l}\text { Location is set on the existing } \\
\text { fault plane that can be up to 3 } \\
\mathrm{km} \text { away from the mine. }\end{array}$ \\
\hline $\begin{array}{l}\text { The rock can crack as the } \\
\text { induced mining stresses } \\
\text { exceed the shear strength of } \\
\text { the rock. Crack planes can be } \\
\text { variously oriented. }\end{array}$ & $\begin{array}{l}\text { Occurs on existing tectonic } \\
\text { faults. Mining can induce the } \\
\text { events on faults with }\end{array}$ \\
\hline $\begin{array}{l}\text { High stress drops are often } \\
\text { observed. }\end{array}$ & $\begin{array}{l}\text { Stress drop is similar to } \\
\text { natural earthquakes. }\end{array}$ \\
\hline $\begin{array}{l}\text { Magnitudes are low to } \\
\text { medium. }\end{array}$ & $\begin{array}{l}\text { High magnitudes are very } \\
\text { likely. }\end{array}$ \\
\hline
\end{tabular}

\section{SEISMICITY IN THE COLLIERY AREA}

In 1999 the Velenje Colliery decided to set up a local observation site network in the Šalek valley. The decision was taken because of rock burst events in the mine and with the goal to locate the hypocenters of quakes better. The strongest quake reached intensity of IV-V after EMS-98 ${ }^{8}$. Until then such measurements were only made in the state-owned observational network. The measurements in mine's local network enable us to locate the weak seismic events in Šalek valley, but only in a range of the coal deposit dimensions. Underground observation sites system setup and calibration has been done by company K-UTEC Sondershausen. ${ }^{9}$ This digital seismic observation sites system for monitoring of rock bursts at longwall faces enables a precise location of seismic wave's source and intensity. ${ }^{9,10,11}$ The surface system setup has been constructed by the Velenje Colliery staff., ${ }^{9,10,11}$ Such a network setup with regular sensor layout can ensure the systems accuracy from \pm 1 $\mathrm{m}$ to $\pm 10 \mathrm{~m} .{ }^{9}$ Based on such a network setup we recorded 289 seismic events, which were also recorded on the state network in 2004. Considering the underground and the surface system of Velenje Colliery there were 106 matches that undoubtedly belong to the Velenje Colliery area. Only four stronger seismic events met the requirements for kinematic analysis of focal quake mecha- 


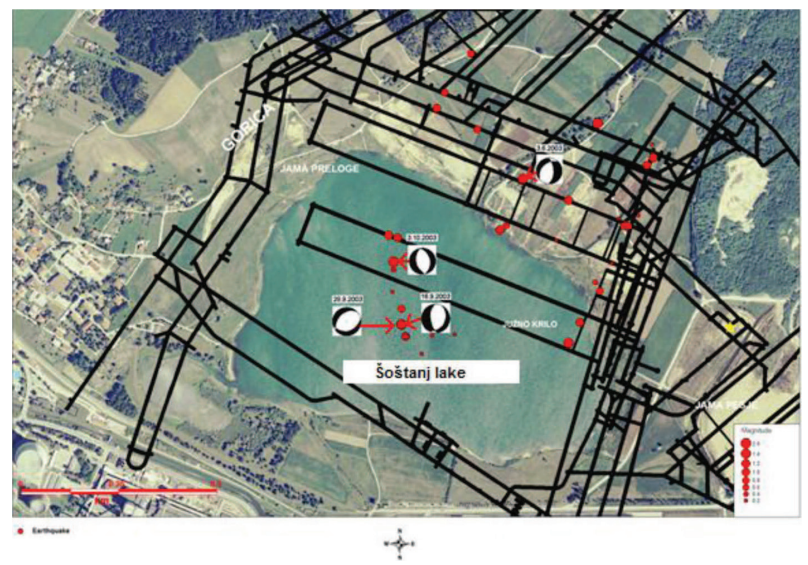

Figure 5: Focal mechanisms of four seismic events of which the signals could be interpreted for first moves

Slika 5: Žariščni mehanizmi štirih seizmičnih dogodkov, katerih signal je mogoče razlagati za prve premike

nism. ${ }^{12}$ Figure 5 shows a certain part of localized events and the four analyzed too.

From analysis of four focal mechanisms in Figure 5, taking into consideration the classification ${ }^{13}$ shown in Figure 6, we can conclude that in all four events it is about the predominant normal component of the fault. We can explain this with sudden stress relaxation together with displacement in a crushed zone corresponding to subsidence due to mining.

The magnitude measurements showed practically insignificant magnitudes between 0 and 0.1 for most events. The next most frequent magnitudes were between 0.5 and 0.9 in 2004 and 2005. The highest magnitude

A

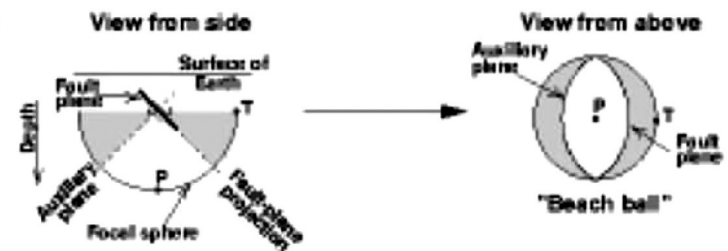

B
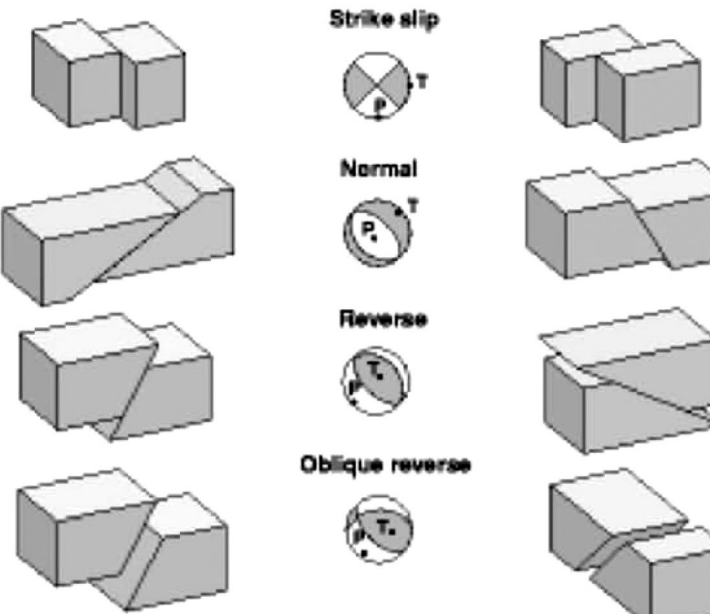

Nermal
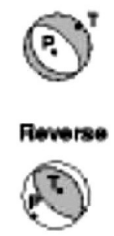

Oblique reverse
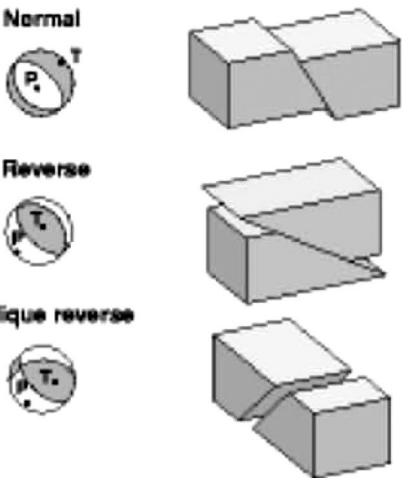

Figure 6: Faults with the corresponding focal mechanisms ${ }^{13}$ Slika 6: Poškodbe z ustreznim žariščnim mehanizmom ${ }^{13}$ was 2.4 in 2003 and 1.6 in 2004. From Graph 1 we can conclude that the majority of the seismic events are not detected by the Šoštanj inhabitants. In the Šalek valley area the state seismic observational network did record one larger event not recorded by the local colliery network. We are not able to locate this event precisely enough without data from local network. Many recorded events in both networks have the dominant event frequency larger than $3 \mathrm{~Hz}$. According to the size and localities of seismic event occurrences it is possible to conclude that all of them are Type-I rock bursts. The only event that could be classified as Type II is the larger one, but there are not enough data to localize it more precisely.

\section{STEEL ARCH SUPPORT AND ROCK BURSTS}

At the moment of rock burst occurrence a powerful collapse of the rock takes place. Rapid excavation is followed by sudden rock collapse parallel to the face, inducing rock bursting. ${ }^{6}$ From experience we know the support damages occur as a consequence of rock bursts (Figure 7). Rock burst reduction can be achieved through some specific measures, one of these being slowdown of the coal production speed, but such a measure is a very undesirable one as the production speed is one of the key parameters of the colliery's economics. ${ }^{14,15}$

Following the reports made in department for safety at work we can find that support damages in the mine rarely exceed $50 \mathrm{~m}$. In the case of shorter damage segments the displacement at joints is larger, but in case of longer damage segments the displacement at joints is smaller. Observations show the possibility of combinations at damage sections up to $50 \mathrm{~m}$ where certain joints get larger and others get smaller deformations or somewhere deformations are not noticeable at all. Figure 7 shows deformations after the rock burst where at the middle two joints the shift is $0.37 \mathrm{~m}$ while the other two

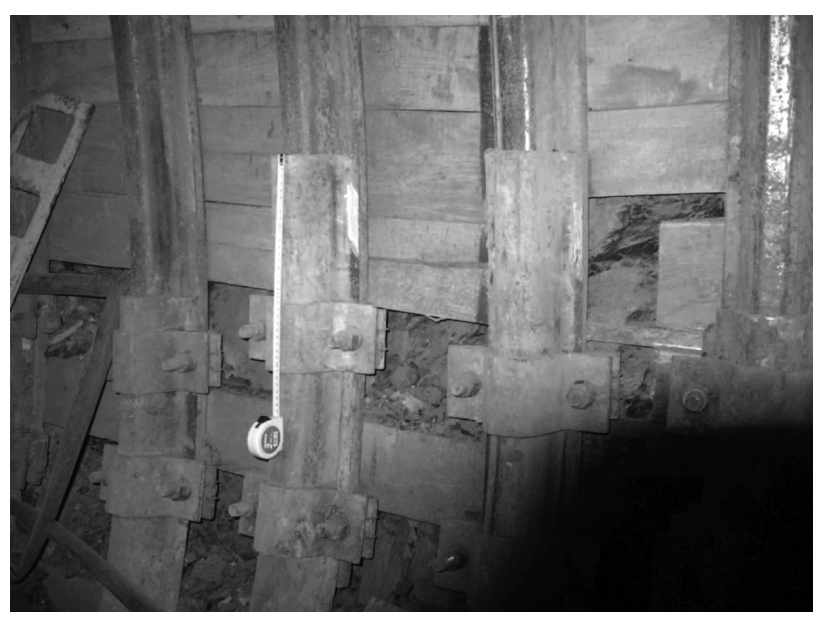

Figure 7: Damages on K24 support after a rock burst Slika 7: Poškodbe na podporju K24 po hribinskem udaru 


\section{MATERIALI IN TEHNOLOGIJE/MATERIALS AND TECHNOLOGY (1967-2017) - 50 LET/50 YEARS}

\section{G. VIŽINTIN et al.: ROCK BURST DEPENDENCY ON THE TYPE OF STEEL ARCH SUPPORT IN THE VELENJE MINE}

joints remained practically without any deformation. In case of this specific rock outburst the damaged section reached $50 \mathrm{~m}$ in length but not all of the joints were equally damaged. Resulting from the Velenje Colliery local seismic network and seismic stations in Slovenia, Italy, Austria, Hungary and Croatia measurements we know that such events rarely exceed 1,5 magnitude after Richter.

In 2011 and 2012 the mechanic characteristics of existing support have been analyzed in context of rock burst exploration. The K24-type steel arch support is currently in use in the Velenje Colliery. This support type is thermally treated (hardened) meaning the arch is more flexible. In cases where larger pressure acts on steel arch support K24 this support reacts in a discontinuous yielding manner (sudden relaxation). The support has been sent to a certified laboratory in Oprava, Czech Republic for a comparative test. For comparison the support type TH29 has been chosen while relaxing the stress in significantly shorter deformation intervals. ${ }^{16}$ Results of the loaded support joint deformations comparative tests are shown in Graph 2. As seen from Graph 2 the majority of TH29 support joints relax the stress in short deformation intervals while this is not the case for joints of the K24 support. Also seen from Graph 2, that compares clamp samples of K24 andTH29 support, the K24 clamp yields at $380 \mathrm{kN}$ load resulting in deformation of 0,031 m momentary displacement. Knowing the deformation displacement on the clamp at given force we can calculate the deformation work with the following Equation (1):

$$
W_{\text {def }}=F \times s
$$

where $W_{\text {def }}$ - deformation work (J), $F$ - force of load $(\mathrm{N})$ and $s$-deformation displacement $(\mathrm{m})$, resulting for one clamp $11.78 \mathrm{~kJ}$. Following the reports made in department for safety at work we can find that support damages in the mine rarely exceed $50 \mathrm{~m}$. Considering the fact that each frame has got seven joints and three frames are installed per one meter of the underground

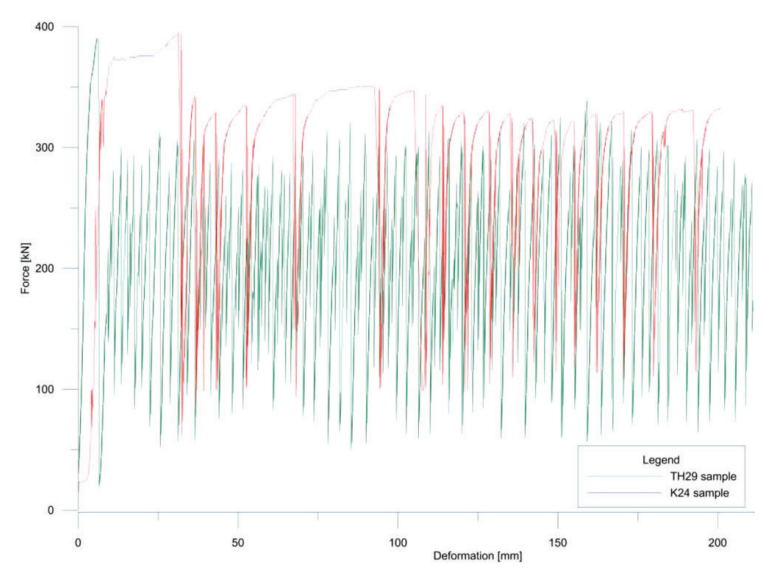

Graph 2: Comparison of stress relaxation on K24 and TH29 support Graf 2: Primerjava sproščanja napetosti na K24 in TH29 podporju roadway we can calculate the number of joints that yield on the length of $50 \mathrm{~m}$ with the next Equation (2):

$$
S_{\text {tot }}=(L \times(N-1)+1) \times S
$$

where $S_{\text {tot }}$ - number of all support joints, $L$ - length in meters, $N$ number of frames per meter and $S$ number of clamps. In case of rock burst in length of $50 \mathrm{~m}$ the number of clamps is 707 . We can make a calculation of common deformation energy needed for deformation of 707 clamps by multiplication of number of clamps and deformation work: 707 clamps $\times 11.78 \mathrm{~kJ} /$ clamp results: 8.34 MJ. Regarding the Equation (3): ${ }^{17}$

$$
M_{\mathrm{L}}=\left(\lg \left(W_{\text {def }} \times 10^{7}\right)-11.8\right) / 1.5
$$

where $M_{\mathrm{L}}$ - local magnitude of seismic waving, this energy is equivalent to Richter local magnitude $M_{\mathrm{L}}=$ 1.41. Graph 3 shows relation between support deformation length and local magnitude $M_{\mathrm{L}}$. From Graph 3 taking into account Graph 1 follows that sudden support yielding rarely exceeds $50 \mathrm{~m}$ length and this complies with rock burst observation experience.

\section{DISCUSSION}

Results of our multiannual research show that it is possible to relate the seismic events and the activities in the Velenje Colliery. Majority of seismic events is very weak and therefore not detectable and do not represent any disturbance to local inhabitants. In spite of the previous fact such events are uncomfortable or even fatal for miners or other workers in the mine. In 1970 the specially adapted longwall mining method was developed that is tailored to great seam thickness and coal seam geometry using mechanized hydraulic shield roof support. This method significantly improved the economics of underground coal production. From the other side, the excavation speed increases the imbalance in the stress state of the fractured and damaged rock behind the longwall face. As a consequence of that inside the rock the stress is accumulated and can be suddenly relaxed,

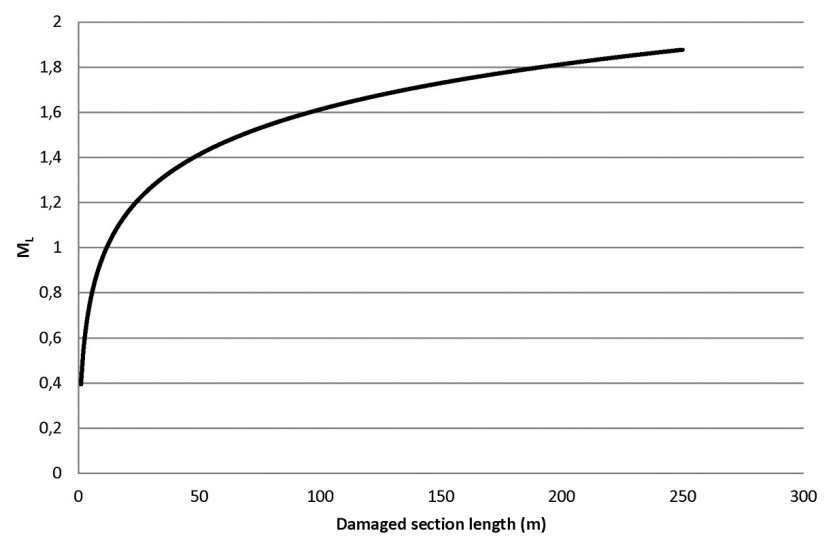

Graph 3: Local magnitude $M L$ size in dependence of damaged section length

Graf 3: Velikost lokalne magnitude $M L \vee$ odvisnosti od dolžine poškodovanega odseka 
causing a rock burst. The coal production speed is economically very important and therefore not to be decreased, but there are some other specific measures that can help to reduce the stress relaxation in the zone of the fractured and damaged rock. Seismic events analysis indicates the possibility to determine the focal points of the most seismic events. It is also possible to establish that most seismic events are under the $M_{\mathrm{L}}=1.5$ value. Regarding their dynamics and localities of seismic events occurrences, it is possible to conclude that all of them are Type-I rock bursts. Until now, the events of Type II were not recorded with the local Velenje Colliery seismic system. Some larger events recorded only in the state network of seismological observation stations indicate the possibility of their presence but without any detection in the local network the precise localization is not possible. Further analysis of satisfactory recorded seismic events in both networks indicates the probability of these seismic events to be a consequence of stress relaxation in fractured rock. As well, from the other side, based on underground observation we know that during rock bursts the deformation of steel arch support is usually not longer than $50 \mathrm{~m}$. In terms of energy this corresponds to measured seismic events in the Velenje Colliery area. It is also true that rock bursts leave effects on shorter distances too but we have to bear in mind that in such cases deformations in clamp areas are larger. In spite of the fact that these statements are initial findings of multiannual research, in our opinion the way of joint deformation on steel arch support is the reason for rock burst occurrence in the Velenje Colliery. Therefore, we suggest that Velenje Colliery as a measure for rock burst reduction starts to substitute the existing K24 support with another one which enables the gradual stress relaxation together with gradual deformation as for example the TH29 support.

Our next suggestion to Velenje Colliery is to consider activities for stress relaxation in spots more exposed to rock bursts. One of these activities might be blasting in flank boreholes filled with minor explosive amounts. Before boring the flank boreholes a very precise micro locations map of potential rock bursts is required. Elaboration of such map requires a fixed underground monitoring system so the existing mobile system needs to be replaced. In addition to improved monitoring system the stress measurements on steel arch support need to start. In case of reaching the limit yield values, a clear danger of rock burst is indicated. Based on better localization and monitoring of stress increase at joints, the precise procedure of preventive blasting will be prescribed.

\section{CONCLUSIONS}

From the research we can see the connection between support type and rock bursts. Support type that blocks continuous stress relaxation in form of minor deforma- tions can cause stress accumulation and in case of overburden the support deformation is large. Such event results the rock burst, hurting people and damaging mine facilities. In order to reduce the rock bursts we suggest to Velenje Colliery the following:

- Start to introduce the steel arch support capable of stress relaxation in form of constant short deformations.

- Set up a fixed rock burst occurrence monitoring system.

- Develop in-seam stress monitoring system (pressure cells installed in rock).

- Test the loaded arch support frames for in-arch stress measurements development.

- Develop relaxation blasting procedures using boreholes.

- Set up rock burst description database.

Ongoing research should be directed into possibility of rock burst Type-II occurrence. These rock bursts can cause more severe seismic events along otherwise stable fault structures that become active because of excavation conditioned disturbed spatial geophysical equilibrium.

\section{Acknowledgments}

This study was financially supported by the research project L1-5451 funded by Slovenian Research Agency (ARRS).

\section{REFERENCES}

${ }^{1}$ A. Brezigar, B. Ogorelec, L. Rijavec, P. Mioč, Geološka zgradba predpliocenske podlage Velenjske udorine in okolice, Ljubljana, Geologija, (1987) 30, 31-65

${ }^{2}$ A. Brezigar, A. Šercelj, F. Velkovrh, D. Vrhovšek, G. Kosi, Paleontološke raziskave pliokvartarne skladovnice Velenjske udorine, Ljubljana, Geološki zbornik, (1983) 3, 31-33

${ }^{3}$ A. Brezigar, Premogova plast Rudnika lignita, Velenje, Ljubljana, Geologija, (1985/86) 28/29, 319-336

${ }^{4}$ F. Žerdin, E. Dervarič, The velenje mining method: a systemof longwall sub-level caving extraction, Glückauf, 134 (1998) 7/8, 383-392

${ }^{5}$ K. S. Guha, Induced Earthquake, Dordrecht: Kluwer Academic Publishers, 2000, 314

${ }^{6}$ P. J. Bardet, Finite Element Analysis of Rockburst as Surface Instability, Elsevier Science Publishers, Computers and Geotechnics, (1989) 8, 177-193, doi:10.1016/0266-352X(89)90042-6

${ }^{7}$ J. C. Johnston, H. H. Einstein, A survey of mining ssociated rockbursts, Proc. $2^{\text {nd }}$ Int. Symp. On Rockburst and Seismicity in Mines, Rotterdam, Balkema 1990, 121-128

${ }^{8}$ J. Bajc, M. Živčić, M. Gostinčar, Seizmična aktivnost v Šaleški dolini spomladi 2002, Potresi, (2004) 2002, 55-70

${ }^{9}$ J. Mayer, M. Mavec, I. Zadnik, R. Lah, Spremljanje rudarsko induciranih seizmičnih pojavov v Premogovniku Velenje, RMZ-mater. geoenviron., (2002) 1, 51-60

${ }^{10}$ J. Likar, E. Dervarič, M. Medved, J. Mayer, G. Vižintin, Monitoring and analyses of seismic events at the Velenje coal mine, Acta geotech. Slov., (2008) 5, 20-28

${ }^{11}$ M. Medved, E. Dervarič, G. Vižintin, J. Likar, J. Mayer, Analysis of seismic events at the Velenje Coal mine, RMZ-mater. geoenviron., (2008) 4, 464-475 


\section{MATERIALI IN TEHNOLOGIJE/MATERIALS AND TECHNOLOGY (1967-2017) - 50 LET/50 YEARS}

G. VIŽINTIN et al.: ROCK BURST DEPENDENCY ON THE TYPE OF STEEL ARCH SUPPORT IN THE VELENJE MINE

${ }^{12}$ T. Živec, Analiza potresne dejavnosti na območju premogovnika Velenje, diplomsko delo, Ljubljana, 2005, 69

${ }^{13}$ A. V. Cronin, A Draft Primer on Focal Mechanism Solution for Geologists, Baylor University, 2004

${ }^{14}$ M. Medved, I. Ristović, J. Rošer, M. Vulić, An overview of two years of continuous energy optimization at the Velenje coal mine, Energies (Basel), (2012) 5, 2017-2029, doi:10.3390/en5062017

${ }^{15}$ I. Ristović, M. Stojaković, M. Vulić, Recultivation and sustainable development of coal mining in Kolubara basin. Therm. sci., (2010) 3, 759-772, doi:10.2298/TSCI091123002R

${ }^{16}$ R. Podjatke, H. Witthaus, J. Breedlove, Development in Steel Roadway Support - A Track Record, $27^{\text {th }}$ International Conferece on Ground Control in Mining, (2008), 358-365

${ }^{17}$ B. Gutenberg, F. C. Richter, Magnitude and Energy of Earthquakes, Science, (1936) 83, 183-185 